\title{
Internet Lite: Short Internet Assignments for American Government Courses
}

\author{
Sue E. S. Crawford, Creighton University
}

$T_{\text {the }}^{\text {he }}$ he Internet can be an important tool for gathering information about politics and for participating in politics. The Internet also provides easy access to a multitude of "real world" examples of concepts discussed in political science classes. These characteristics of the Internet, along with student enthusiasm about the Internet, have resulted in great interest in incorporating the Internet into introductory American politics courses. Informal discussion with other faculty members suggests that three challenges prevent many from using the Internet in American government courses outside of course listservs or chat rooms: (1) the inability to devote sufficient time to creating meaningful web-based course materials; (2) a concern that available web-based course materials do not sufficiently move beyond instruction possible through traditional texts; and (3) a limited availability of quality computer projection or inclass computer facilities, which makes using web materials in the classroom very difficult.

A short assignment approach to using the Internet in introductory American government courses overcomes each of the three obstacles. It requires minimal preparation time. The assignments add value to the course by taking full advantage of the flexibility of the Internet and by focusing on skill development. Since students complete the assignments out of class, neither classroom computers nor

Sue E.S. Crawford is an assistant professor in the department of political science and international studies at Creighton University, where she teaches courses in American politics and public policy. She has published in American Political Science Review and currently serves on the editorial board for Nonprofit and Voluntary Sector Quarterly. computer projection in the classroom are needed.

This article describes three short Internet assignments that I use in my introductory American government courses and students' evaluations of the assignments. The assignments can stand alone as the sole Internet element in a course (Internet Lite) or they can be used in a course with other Internet components. Here, I focus on the three assignments I have used. However, the short assignment approach could easily be expanded to include more assignments or adapted to include a different set of assignments. The appendix lists seven additional short assignment ideas for American government courses.

\section{Benefits of the Assignments}

The learning objectives of the short Internet assignments are consistent with the objectives of most American government courses. The two main objectives are: (1) students improve their comprehension of political science concepts, patterns of political behavior, and government structures; and (2) students improve their information seeking skills. Each of the assignments discussed also incorporates specific political science skills, Internet skills, and civic skills. Figure 1 lists the target skills for the three short assignments.

The assignments focus on developing independent Internet skills. Students learn to navigate the Internet on their own. After they leave the class, they will be able to walk into a public library or subscribe to an Internet service and find political sites on their own.

One of the major benefits of the assignments is their flexibility. Students pursue topics related to the current course material that are of most interest to them. They can visit their hometown's city council web site, find interest groups that address issues of interest to them, or find a site that allows them to send messages to a Senator that they saw on CNN the night before.

The approach requires minimal equipment; only student access to a computer lab with Internet access is necessary. The assignment approach does not require setting up a course web page, nor does it require a quality computer screen projector in the classroom. Unlike a course web page, the assignments require little investment in preparation and updating. The assignments only require preparation of handouts that describe the assignments and provide information on using the Internet programs available on the computers in the university computer labs. The assignments add more to the course, though, if the instructor also takes the time to structure some class discussion around the assignments. Class discussion allows students to hear about other Internet sites. More importantly, it allows the class to see a variety of examples of the political science concepts addressed in the assignment. Quality discussion can challenge students to interpret what they found in the context of course readings and earlier class discussions.

\section{The Assignments}

The short assignments I use focus on the topics of political participation, interest groups, and legislatures. The first assignment takes students through the use of links to find new sites. The second takes students through the steps of using Internet directories, and the third requires them to use one of those two methods again.

Students receive the assignments in class or on the course listserv. Handouts for the assignments in- 
clude a description of the assignment and supplemental information on using the Internet. Students generally have a week to complete the assignments. Copies of class handouts can be obtained from the author. ${ }^{1}$

\section{Political Participation and Internet Links}

The first assignment requires students to find a site that provides an email address for an elected official or a reply function that allows citizens to send messages to an elected official. Each student turns in the URL or the email address for an elected official along with a letter to that elected official. I do not require students to actually send the letter. However, students must compose a letter and find an Internet mechanism that could be used to send the letter. The letter must advocate an issue position or ask for specific information on a policy issue. This assignment has the added advantage of encouraging students to use information that they gather through following the news during the semester.

The assignment handout provides students with basic instructions on using links, instructions to get to a web site that includes links to other web sites, and tips on writing a letter to an elected official. I direct students to the Creighton Political Science home page (http://puffin. creighton.edu/pls/index.htm), which provides links to other political web sites. Instructors with course web sites that include links can obviously direct students to start there. Directing students through links does require scouting for one good starting point. However, all that is really required for the first assignment is a page with a link to Thomas, the Library of Congress web site (www. loc.gov) and a link to the White House (www.whitehouse.gov).

If students successfully complete the first assignment, they practice a target civic skill and a target Internet skill. Specifically, they find a means of communicating with elected officials and they learn to use links to find Internet sites. Class discussion of the assignment can build on the

\section{Figure 1}

\section{Target Skills of the Internet Assignments}

\section{Political Science Skills}

Recognize the variety and relative ease of participation options for citizens with Internet resources.

Recognize efforts by interest groups to use the Internet for grassroots lobbying and information campaigns.

Recognize structures and issues relevant to different state and local legislative bodies.

\section{Citizenship Skills}

Find methods of communicating with elected officials through the Internet.

Find information on how to join interest groups.

Find information on the agendas and activities of state and local legislative bodies.

Internet Skills

Learn to use links to find Internet sites.

Learn to use directories to find Internet sites.

Learn to use reply options and email addresses to participate in political dialogue.

discussion of income and education gaps in participation that is part of most American government courses. Discussion can emphasize the relative ease of participation for people with Internet access and help students to recognize the implications of unequal access to Internet resources. One might tie this assignment to service learning objectives by challenging students to develop proposals for improving Internet access for people with low incomes or low levels of education.

\section{Interest Groups and Internet Directories}

The second assignment requires students to use a directory to find an Internet site for an interest group web site. They then turn in a report that lists the name of the group, the URL address for the group, the issues of the group, the information that the site provides about how to join the group, and a description of how the interest group uses the web site to employ a grass roots strategy
TABLE 1

Student Perceptions of their Achievement of the Learning Objectives

\begin{tabular}{lccc}
\hline \multicolumn{1}{c}{ Question } & $\begin{array}{c}\text { All } \\
\text { Agrees }\end{array}$ & $\begin{array}{c}\text { Strongly } \\
\text { Agree }\end{array}$ & $\begin{array}{c}\text { All } \\
\text { Disagrees }\end{array}$ \\
\hline $\begin{array}{l}\text { I now feel more confident in my ability to find } \\
\text { information about U.S. political groups and } \\
\text { government institutions. }\end{array}$ & $83 \%$ & $52.5 \%$ & $6.8 \%$ \\
$\begin{array}{l}\text { I am more likely to use the Internet to find } \\
\text { information about politics or government. }\end{array}$ & 78 & 49.2 & 8.5 \\
$\begin{array}{l}\text { I am more likely to participate in politics } \\
\text { through the Internet. }\end{array}$ & 52.5 & 25.4 & 23.7 \\
\hline
\end{tabular}

Notes: $N=59$. Respondents are students in fall 1996 and spring 1997 sections of American Government and Politics at Creighton University. Respondents could select from the following: strongly agree, agree, neutral, disagree, strongly disagree, or don't know. 


\section{TABLE 2}

\section{Perceived Outcomes for Students with Less Confidence in} Their Internet Skills Prior to the Course

\begin{tabular}{|c|c|c|c|}
\hline Question & $\begin{array}{c}\text { All } \\
\text { Agrees }\end{array}$ & $\begin{array}{l}\text { Strongly } \\
\text { Agree }\end{array}$ & $\begin{array}{l}\text { All } \\
\text { Disagrees }\end{array}$ \\
\hline $\begin{array}{l}\text { I now feel more confident in my ability to find } \\
\text { information about U.S. political groups and } \\
\text { government institutions. }\end{array}$ & $\begin{array}{c}16 \\
84.2 \%\end{array}$ & $\begin{array}{c}12 \\
63.2 \%\end{array}$ & $.05 \%$ \\
\hline $\begin{array}{l}\text { I am more likely to use the Internet to find } \\
\text { information about politics or government. }\end{array}$ & $\begin{array}{c}15 \\
78.9 \%\end{array}$ & $\begin{array}{c}12 \\
63.2 \%\end{array}$ & $\begin{array}{c}3 \\
15.8 \%\end{array}$ \\
\hline $\begin{array}{l}\text { I am more likely to participate in politics } \\
\text { through the Internet. }\end{array}$ & $\begin{array}{c}10 \\
55.6 \%\end{array}$ & $\begin{array}{c}6 \\
31.6 \%\end{array}$ & $\begin{array}{c}6 \\
31.6 \%\end{array}$ \\
\hline
\end{tabular}

or an information campaign strategy. The assignment requires that either class readings or class discussions define grass roots strategies and information campaign strategies.

The handout for the assignment provides information on using search engines. It provides information on the directory options in Netscape or Microsoft Explorer and gives the address of the Lycos directory (www.lycos.com).

Students who successfully complete the second assignment practice three target skills. They learn to recognize efforts by interest groups to use grass roots lobbying or information campaigns (a political science skill), and they learn how to join a political interest group (a civic skill). They also learn how to use directo- ries to find political information (an Internet skill).

Class discussion of interest group web sites can address some of the following questions: Were the information campaigns convincing? Did the web site make it easy for people to participate in grass roots lobbying? Did the group provide selective incentives to encourage membership? The variety of interest group sites discovered and the marginality of some of the groups that have sites (e.g., "Government is Not God" [www.govnotgod.org]) can make class discussion of the sites entertaining as well as educational.

\section{TABLE 3}

\section{Student Satisfaction with Internet Assignments}

\begin{tabular}{lccc}
\hline \multicolumn{1}{c}{ Question } & $\begin{array}{c}\text { All } \\
\text { Agrees }\end{array}$ & $\begin{array}{c}\text { Strongly } \\
\text { Agree }\end{array}$ & $\begin{array}{c}\text { All } \\
\text { Disagrees }\end{array}$ \\
\hline $\begin{array}{l}\text { The information assignments directed me to } \\
\text { useful sources of information. }\end{array}$ & $89.9 \%$ & $44.1 \%$ & $5.1 \%$ \\
$\begin{array}{l}\text { The information assignments were flexible } \\
\text { enough to allow me to search for information } \\
\text { that I found interesting. }\end{array}$ & 93.3 & 49.2 & 0 \\
$\begin{array}{l}\text { I would recommend keeping the information } \\
\text { assignments as part of this course. }\end{array}$ & 83 & 55.9 & 6.8 \\
\hline $\begin{array}{l}\text { Notes: N }=59 \text {. Respondents are students in Fall } 1996 \text { and Spring } 1997 \text { sections } \\
\text { of American Government and Politics at Creighton University. }\end{array}$ &
\end{tabular}

\section{Other Legislatures}

The third assignment requires students to use either links or directories to find an Internet site for a state legislature, city council, county commission, or school board. Each student submits a report that lists the search strategy used, the Internet address of the site visited, a general description of the kinds of information available at the site, and one piece of useful or interesting information that was found on the site.

This assignment does not require Internet instructions. Students have used both links and directories in earlier assignments and they can refer to previous handouts for assistance. Completing the assignment requires no additional information about state or local legislatures. Class discussion of the assignments can help students understand similarities and differences between Congress and other legislatures.

Nearly all Internet sites for other legislatures provide agendas for meetings or hearings, which allow students to see what kinds of issues state and local legislatures address. Some sites also describe the structure of the legislature. Students who complete the assignment recognize some of the issues and structures of state and local legislatures (a political science skill). Class discussion allows students to hear about the issues on the agenda for other legislatures and to understand better the range of issues that state and local legislatures address. Students who complete the assignment also learn how to find information on the agenda and activities of a state or local legislature (a target citizenship skill). Although the citizenship skill may seem simple, it is empowering. Students are often excited to learn that they can find meeting agendas for their hometown city councils.

\section{Student Evaluations}

Students complete an evaluation of the Internet assignments on the same day that they complete teaching evaluations. The evaluation results are responses from students enrolled in sections of American 
Government and Politics in the fall 1996 and spring 1997 semesters.

The evaluation form consists of a set of statements and boxes that students check to indicate the extent to which they agree with the statements. Most of the statements evaluate the extent to which students feel that they have met the learning objectives of the assignments or the extent to which they were satisfied with the assignments. A couple of statements measure the extent to which students used the Internet before taking the course.

The evaluation results, then, reflect the extent to which students agree or disagree with statements about the assignments. This raises the important caveat that the method measures student perceptions. For example, high levels of student agreement that they are more likely to use the Internet to find information on politics is an indication that students felt the assignments helped them meet the objective of increasing Internet usage. It is not a measure of actual increases in students' use of the Internet to find political information. Despite the limitations of student perceptions, they do provide a means for examining the potential value of the Internet assignments for introductory American politics students.

\section{Evaluation Results}

Table 1 lists the extent to which students agreed that they met the learning objectives of the assignments. Most students agree that they improved their Internet skills and that, after completing the course, they are more likely to use the Internet to find information about politics or government. Students agree that they had improved their skills, even though $83 \%$ of the students had previous Internet experience. Half of the students predict that they are more likely to participate in politics through the Internet. It is possible that participation through traditional means could also increase due to an increased ability and likelihood to use the Internet to find information on politics and on how to participate.

According to the evaluation sur-

\section{Appendix}

\section{Additional Internet Assignments}

\section{The Constitution and Civil Liberties}

Several states have copies of their constitutions online. Find a site that includes the full text of a state constitution. List the URL address for the site. List an article or amendment of the constitution that protects individual citizens of that state from government action. Explain how this protection is the same as a protection in the U.S. Constitution or how the protection is an additional protection.

\section{Campaigns}

Find a web site for a political candidate. List the URL address for the site. Describe the options that the web site offers for citizens to be involved in the campaign. Discuss how the material on the web site is consistent with one of the campaign strategies that we discussed in class.

\section{Campaign Finance}

Find the web site for the Federal Election Commission. Find summaries of campaign contributions for House races. List the URL address. Describe one pattern in contributions to House races that you find interesting.

\section{Executive}

Find the web site for the president or for a governor. List the URL address. If you choose a governor, list the name and state of the governor. Is there evidence that the web site is used to build public support for policy issues? If so, describe one example.

\section{Congress-Committees and Oversight}

Use the directories in Thomas to find an oversight schedule for a congressional committee. List the name of the committee and the URL address. Briefly describe two oversight activities listed on the committee's schedule. List the name and email address of the chair of the committee.

\section{Bureaucracy}

Find a web site for a federal or state agency. List the URL address. Considering the information on the web site, briefly describe the mission of the agency. What policy choices might bureaucrats from the agency advocate in order to expand the activities that fit their mission?

\section{Judiciary}

Find a web site that lists Supreme Court decisions and opinions. Find a specific recent case. List the URL address for the site, the name of the case, and the decision. Briefly describe the constitutional issue of the case. What constitutional amendments or clauses appear to be most important in the case?

vey, 19 students did not feel confident in their Internet skills before taking the course. Table 2 lists the evaluation results for those students. Overall, students who entered the class with the least confidence in their Internet skills were more likely to agree that they had met the learning objectives. On the one hand, that may be a simple function of the fact that they knew less before the course. It is easier for them to feel that they had improved their abilities. On the other hand, the results suggest that even students who may not be very comfortable with com- puters are able to feel that their computer skills improve through completing the assignments.

Table 3 lists student responses to statements about their satisfaction with the assignments. Nearly $90 \%$ of the students feel that the assignments directed them to useful sources of information. Only $5 \%$ disagree. The assignments allow students to visit sites that interest them and students appear to appreciate this flexibility. No one disagrees with the statement that the assignments were flexible enough to allow them 
to search for information that they

found interesting.

The most general measure of satisfaction is whether the students would recommend keeping the assignments as part of the course. As shown in Table 3 , most students agreed that the assignments should remain part of the course. In all, students registered high satisfaction with the assignments.

The evaluation results suggest that the Internet assignments meet at least two of the three learning objectives quite well. Most students felt that the assignments improved their ability to use the Internet to find political information and most felt that the assignments increased the likelihood that they will use the Internet to find political information. Students also registered high levels of satisfaction with the short Internet assignments. The results indicate that students recognized the value of the assignments, that they appreciated the flexibility of the assignments, and that they would recommend the use of the assignments for future introductory American government courses.

\section{Conclusion}

The useful target skills of the assignments and the high student evaluations of the assignments suggest that the assignments can add value to introductory American government courses. The ease with which the short assignments can be prepared and the minimal equipment requirements of the assignments make the approach feasible for most instructors. The assignments provide a means for American government faculty to gain many of the advantages of the Internet right now without learning to use a new program or waiting for quality classroom computing facilities. As campus computer facilities improve and webbased instructional programs get easier to use, the assignments can remain a part of Internet-intensive courses. The emphasis on independent searches in the assignments can complement the use of web-based instructional materials that take students to specific Internet sites. Regardless of the level of other Internet use in a course, faculty can make use of the political science and civic components of the assignments to enhance American government courses.

\section{Note}

1. Send requests to: Sue Crawford, Department of Political Science and Internationa? Studies, Creighton University, Omaha, NE 68178; Email: crawford (ucreighton.edu. 